\title{
FAKTOR - FAKTOR YANG BERHUBUNGAN DENGAN KEJADIAN STUNTING DI KECAMATAN CIGANDAMEKAR KABUPATEN KUNINGAN
}

\author{
${ }^{1}$ Evi Soviyati, ${ }^{2}$ Toto Sutarto Gani Utari, ${ }^{3}$ Seli Marselina \\ ${ }^{1,3}$ Sekolah Tinggi Ilmu Kesehatan Kuningan, ${ }^{2}$ Universitas Pasundan \\ eviesofia73@gmail.com
}

\begin{abstract}
Abstrak
Stunting/pendek merupakan penggambaran dari status gizi kurang yang bersifat kronik pada masa pertumbuhan dan perkembangan sejak awal kehidupan. Banyak faktor yang dapat menyebabkan terjadinya stunting pada balita. Penelitian ini bertujuan untuk mengetahui faktorfaktor yang berhubungan dengan kejadian stunting di Kecamatan Cigandamekar Kabupaten Kuningan. Metode yang digunakan adalah analitik observasional dengan pendekatan case control, penelitian dilakukan dengan mengambil data primer. Populasi penelitian seluruh balita stunting di Kecamatan Cigandamekar. Pengambilan sampel dalam penelitian ini menggunakan metode purposive sampling. Hasil penelitian analisa univariat dari 100 balita menderita stunting, pemberian ASI 64 orang (64.0\%), riwayat berat badan lahir normal 58 orang atau $(58.0 \%)$, status gizi baik 61 orang atau $(61.0 \%)$. Hasil dari analisis bivariat diketahui bahwa pemberian ASI dengan balita stunting pendek 61 orang atau 95.3\%, BBL normal >2500 dengan balita stunting 41 orang atau $70.7 \%$, status gizi baik dengan balita stunting 48 orang atau $78.7 \%$. Pemberian ASI ( $p$ - value=0,000, OR=101667), berat badan lahir ( $\mathrm{p}$-value=0,356, $\mathrm{OR}=1.484)$, status gizi ( $\mathrm{p}$-value $=0,002, \mathrm{OR}=3.887$ ). Kesimpulan terdapat hubungan antara Pemberian ASI, dan status gizi terhadap kejadian stunting. Dengan demikian diharapkan dapat meningkatkan pemberian ASI dan porsi makanan yang bergizi, sehingga kejadian stunting tidak terjadi, dan Indonesia menjadi bebas stunting.
\end{abstract}


JOURNAL OF MIDWIFERY CARE :

VOL. 01 No. 02, JUNI 2021

DOI: 10.34305/jmc.v1i02.299
Ciptaan disebarluaskan di bawah

Lisensi Creative Commons Atribusi-NonKomersialBerbagiSerupa 4.0 Internasional.

\section{Pendahuluan}

Stunting pada anak merupakan proses kumulatif yang terjadi saat kehamilan masa kanak- kanak dan sepanjang siklus kehidupan. Stunting terjadi karena faktor penyebab seperti genetic, riwayat berat lahir, riwayat penyakit infeksi, pendapatan orangtua, jenis kelamin, umur, status gizi, sangat mempengaruhi kejadian stunting.

Pendek atau stunting (short stature) dengan indikator TB-PB/U digunakan sebagai indikator gizi salah kronik yang menggambarkan riwayat kurang gizi anak dalam jangka waktu lama berdasarkan Kementerian Kesehatan Republik Indonesia (keputusan menteri kesehatan Nomor: 995/MENKES/SK/XXII/2010 tanggal 30 Desember 2010), (2010), tentang standar antropometri penilaian status gizi anak, pengertian pendek dan sangat pendek adalah status gizi yang didasarkan pada indeks panjang badan menurut umur $(\mathrm{PB} / \mathrm{U})$ atau tinggi badan menurut umur $(\mathrm{TB} / \mathrm{U})$ yang merupakan padanan istilah stunting (pendek) dan severely (Wiyono, 2016).

Prevalensi stunting di beberapa negara di Asia Tenggara, seperti Myanmar sebesar 35\%, Vietnam sebesar 23\% dan
Thailand sebesar 16\%. Prevalensi stunting di Indonesia menurut Kementerian Kesehatan Republik Indonesia (2010), Indonesia sebesar $37,2 \%$, meningkat dari tahun 2010 sebesar $35,6 \%$ dan pada tahun 2007 sebesar 36,8\%. Artinya, pertumbuhan tak maksimal diderita sekitar 8 juta anak di Indonesia, atau satu dari tiga anak di Indonesia.

Prevalensi stunting bahkan lebih tinggi dibandingkan dengan permasalahan gizi pada balita lainnya seperti gizi kurang $(19,6 \%)$, kurus $\quad(6,8 \%), \quad$ dan gemuk(11,9\%) (Kementerian Kesehatan Republik Indonesia, 2010). Menurut Dinas Kesehatan Provinsi Jawa Barat (2016).

Masalah stunting/pendek pada balita menunjukan rerata Jawa Barat 35,3\% yang juga lebih baik dari angka Nasional $(37,2 \%)$. Prevalensi yang tertinggi di Kabupaten Bandung. Bandung Barat $(52,5 \%)$ dan terendah di kota Depok $(25,7 \%)$. Salah satu indikator untuk menentukan anak yang harus dirawat jalan manajemen gizi buruk adalah keadaan sangat kurus yaitu anak dengan nilai $\mathrm{Z}-$ score $<-3,0$ SD. Jumlah kasus stunting terbanyak di Kabupaten Kuningan Kecamatan Cigandamekar yaitu sebanyak 
JOURNAL OF MIDWIFERY CARE :

VOL. 01 No. 02, JUNI 2021

DOI: 10.34305/jmc.v1i02.299
Ciptaan disebarluaskan di bawah

Lisensi Creative Commons Atribusi-NonKomersialBerbagiSerupa 4.0 Internasional.
497 kasus (20,2\%) Dinkes Kabupaten Kuningan (2017), menurut data dari UPTD

Puskesmas Cigandamekar Pada tahun 2018 jumlah stunting di Kecamatan Cigandamekar sebanyak 368 yaitu $(15,85 \%)$.

Kementerian Kesehatan Republik Indonesia (2010), hingga saat ini gizi kurang pada balita juga masih menjadi masalah kesehatan masyarakat di berbagai negara, termasuk Indonesia. Beberapa masalah kekurangan gizi pada balita dapat diketahui melalui beberapa indikator. Indikator tersebut diantaranya berat kurang atau underweight jika dilihat dari berat badan umur $(\mathrm{BB} / \mathrm{U})$, pendek atau stunting jika dilihat dari tinggi badan (TB/U) dan kurus atau wasting jika dilihat dari badan menurut tinggi badan (BB/TB). Dalam hal ini, berat kurang dan kurus merupakan dampak masalah kekurangan gizi yang bersifat akut, sedangkan pendek merupakan manifestasi kekurangan gizi yang bersifat kronis.

Berdasarkan Hasil Penelitian Ni'mah K., (2015), menunjukan bahwa panjang badan lahir yang rendah $(\mathrm{OR}=4,091 ; \mathrm{CI}=1,162-14,397)$, balita yang tidak mendapatkan ASI Eksklusif $(\mathrm{CI}=1,328-16,233)$,pendapatan keluarga yang rendah $(\mathrm{OR}=3,250 ; \mathrm{CI}=1,150$ 9,187),pendidikan ibu yang rendah $(\mathrm{OR}=3,378 ; \quad \mathrm{CI}=1,246-9,157), \quad$ dan pengetahuan gizi ibu yang kurang $(\mathrm{OR}=3,250 ; \mathrm{I}=1,140-10,658)$ merupakan faktor yang berhubungan dengan kejadian stunting pada balita.

Hasil penelitian yang dilakukan oleh Laala K.C.G., Punuh M.I. \& N.H., (2018), didapatkan juga hasil tinggi badan ayah yang pendek sebesar $14,7 \%$ dan tinggi badan ibu yang pendek sebesar $23,3 \%$. Hasil penelitian menggunakan chi- square $(\alpha$ $=0,05)$ dan diperoleh hasil terdapat hubungan antara tinggi badan ayah dengan kejadian stunting pada anak usia 24-59 bulan di Kecamatan Tombatu Utara Minahasa Tenggara dengan $\mathrm{p}$ value $=0,006$ $(\alpha=<0,05)$ dan terdapat hubungan antara tinggi badan ibu dengan kejadian stunting pada anak usia 24-59 bulan di Kecamatan Tombatu Utara Minahasa Tenggara $p$ value $=0,000(\alpha=<0,05)$.

Berdasarkan hasil studi pendahuluan di Kecamatan Cigandamekar terdapat 10 desa yang mengalami kejadian stunting dan terbanyak di desa Karangmuncang yaitu berjumlah 65 kasus $(21,5 \%)$ balita yang mengalami kejadian stunting. Hasil 
JOURNAL OF MIDWIFERY CARE :

VOL. 01 No. 02, JUNI 2021

DOI: $10.34305 / j m c . v 1 i 02.299$
Ciptaan disebarluaskan di bawah

Lisensi Creative Commons

Atribusi-NonKomersial-

BerbagiSerupa 4.0 Internasional.

wawancara yang dilakukan di desa jumlah sampel dalam penelitian ini Karangmuncang kurangnya sanitasi didapatkan 100 balita.Variabel bebas dalam lingkungan, pola asuh yang kurang baik, faktor keturunan (genetic), ASI eksklusif, status gizi. Dengan 7 responden ibu balita yang mengalami stunting, maka penelitian tertarik untuk melakukan penelitian yang berjudul "faktor-faktor yang mempengaruhi kejadian stunting di Kecamatan Cigandamekar".

\section{Metode}

Jenis penelitian yang digunakan dalam penelitian ini adalah jenis penelitian Analitik.Rancangan penelitian ini adalah cross sectional.Populasi dalam penelitian ini adalah balita mengalami stunting di wilayah Kecamatan Cigandamekar Kabupaten Kuningan sejumlah 368 balita.

Sampel menggunakan random sampling dimana seluruh balita stunting memiliki kesempatan untuk diteliti dan penelitian ini terdiri dari pemberian ASI, riwayat berat badan lahir, status gizi. Dalam penelitian ini variabel terikat adalah faktorfaktor yang mempengaruhi kejadian stunting.

Instrumen dalam penelitian ini adalah menggunakan kuesioner yang berisi tentang pemberian ASI, Riwayat berat badan lahir balita, status gizi, untuk mengetahui faktor-faktor yang mempengaruhi kejadian stunting.

\section{Hasil}

Analisis Univariat

Berdasarkan hasil penelitian yang dilakukan di Kecamatan Cigandamekar Kabupaten Kuningan tentang faktor- faktor yang mempengaruhi kejadian stunting, maka didapatkan hasil sebagai berikut:

Tabel 1. Distribusi Frekuensi pemberian ASI, Berat Badan Lahir, Status Gizi dan Stunting pada Balita di Kecamatan Cigandamekar

\begin{tabular}{lcc}
\hline \multicolumn{1}{c}{ Variabel } & Frekuensi & Persentase (\%) \\
\hline Pemberian ASI & & 36.0 \\
Tidak ASI & 36 & 64.0 \\
ASI & 64 & 100 \\
Total & 100 & \\
\hline Berat Badan Lahir & & 42.0 \\
BBLR $<2500$ & 42 & 58.0 \\
BBL Normal $>2500$ & 58 &
\end{tabular}




\begin{tabular}{|c|c|c|}
\hline Variabel & Frekuensi & Persentase $(\%)$ \\
\hline Total & 100 & 100 \\
\hline \multicolumn{3}{|l|}{ Status Gizi } \\
\hline Kurang & 39 & 39.0 \\
\hline Baik & 61 & 61.0 \\
\hline Total & 100 & 100 \\
\hline \multicolumn{3}{|l|}{ Stunting } \\
\hline Sangat pendek & 33 & 33.0 \\
\hline Pendek & 67 & 67.0 \\
\hline Total & 100 & 100 \\
\hline
\end{tabular}

Berdasarkan tabel 1 dapat diketahui bahwa dari 100 responden, sebagian besar balita stunting tidak ASI dengan frekuensi 36 orang atau $36.0 \%$, balita stunting yang diberikan ASI dengan frekuensi 64 orang atau $64.0 \%$. Berikut ini digambarkan distribusi frekuensi Berat Badan Lahir (BBL) di Kecamatan Cigandamekar

Pada Tabel 1 diatas juga dapat diketahui bahwa dari 100 responden, sebagian besar balita stunting berat badan lahir rendah $<250042$ orang atau $42.0 \%$, balita stunting dengan bbl normal $>2500$ dengan frekuensi 58 orang atau 58.0\%.

Berikut ini gambarkan distribusi frekuensi status gizi balita di Kecamatan Cigandamekar Kabupaten Kuningan

Berdasarkan hasil penelitian didapatkan dari 100 responden, balita stunting status gizi baik dengan frekuensi 61 orang atau $61.0 \%$. Berikut ini digambarkan distribusi frekuensi stunting balita di Kecamatan Cigandamekar Kabupaten Kuningan. Selain itu dari 100 responden, sebagian besar balita stunting sangat pendek dengan frekuensi 33 orang atau 33.0\%, balita stunting (pendek) dengan frekuensi 67 orang atau $67.0 \%$.

\section{Analisis Bivariat}

Untuk mengetahui hubungan antara variabel bebas ( Pemberian ASI, Riwayat Berat badan lahir, Status Gizi) terhadap variabel terikat (stunting), maka penulis melakukan analisis variabel dengan ketentuan jika nilai $\mathrm{p}$ value $<0.05$ maka terdapat hubungan atau Ho ditolak dan $\mathrm{Ha}$ diterima.

1. Hubungan kejadian stunting dengan kejadian pemberian ASI. 
Tabel 2. Hubungan antara pemberian ASI dengan Stunting di Kecamatan Cigandamekar Kabupaten Kuningan

\begin{tabular}{|c|c|c|c|c|c|c|c|c|}
\hline \multirow{3}{*}{$\begin{array}{c}\text { Pemberian } \\
\text { ASI }\end{array}$} & \multicolumn{4}{|c|}{ Balita stunting } & & & \multirow{3}{*}{ OR } & \multirow{3}{*}{ P-value } \\
\hline & \multicolumn{2}{|c|}{ Sangat pendek } & \multicolumn{2}{|c|}{ Pendek } & \multicolumn{2}{|c|}{ Total } & & \\
\hline & $\mathrm{F}$ & $\%$ & $\mathrm{~F}$ & $\%$ & $\mathrm{~F}$ & $\%$ & & \\
\hline Tidak ASI & 30 & $83.3 \%$ & 6 & $16.7 \%$ & 36 & 100 & 61667 & $0 \Omega 0 \Omega$ \\
\hline ASI & 3 & $4.7 \%$ & 61 & $95.3 \%$ & 64 & 100 & & \\
\hline
\end{tabular}

Berdasarkan tabel 2 menunjukan bahwa dari 100 responden, sebagian besar balita stunting yang tidak diberi ASI berjumlah 30 orang atau $83.3 \%$, sedangkan balita stunting yang diberi ASI berjumlah 6 orang atau $95.3 \%$. Berdasarkan hasil uji statistik dengan menggunakan uji chi square dengan menggunakan program SPSS diperoleh p- value yaitu 0.000 maka dapat disimpulkan bahwa, p-Value sebesar $0.000<0,05$, sehingga $\mathrm{Ha}$ diterima artinya ada pengaruh antara pemberian ASI dengan kejadian stunting. Perhitungan nilai odds Ratio (OR) diperoleh nilai yang menyebabkan efek OR=101.667 kali mengalami stunting.

Tabel 3. Hubungan antara berat Badan Lahir dengan Kejadian Stunting di Kecamatan Cigandamekar Kabupaten Kuningan

\begin{tabular}{|c|c|c|c|c|c|c|c|c|}
\hline \multirow{3}{*}{ Riwayat BBL } & \multicolumn{4}{|c|}{ Balita stunting } & \multicolumn{2}{|c|}{ Total } & \multirow{3}{*}{ OR } & \multirow{3}{*}{ p-value } \\
\hline & \multicolumn{2}{|c|}{ Sangat Pendek } & \multicolumn{2}{|c|}{ Pendek } & \multirow[b]{2}{*}{$\mathrm{F}$} & \multirow[b]{2}{*}{$\%$} & & \\
\hline & $\mathrm{F}$ & $\%$ & $\mathrm{~F}$ & $\%$ & & & & \\
\hline $\mathrm{BBL}<2500$ & 16 & $38.1 \%$ & 6 & $61.9 \%$ & 2 & 100 & \multirow{2}{*}{1.484} & \multirow{2}{*}{0.356} \\
\hline BBL Normal > 2500 & 17 & $29.3 \%$ & 1 & $70.7 \%$ & 8 & 100 & & \\
\hline
\end{tabular}

Berdasarkan tabel 3 menunjukan bahwa dari 100 responden, sebagian besar balita stunting sangat pendek dengan berat OPEN $\bigcirc$ ACCESS badan lahir rendah $<2500$ berjumlah 16 orang atau $38.1 \%$, sedangkan balita stunting secara pendek dengan berat badan lahir 
JOURNAL OF MIDWIFERY CARE :

VOL. 01 No. 02, JUNI 2021

DOI: 10.34305/jmc.v1i02.299
Ciptaan disebarluaskan di bawah

Lisensi Creative Commons Atribusi-NonKomersialBerbagiSerupa 4.0 Internasional. normal $>2500$ berjumlah 41 orang atau 70.7\%.Berdasarkan hasil uji statistik dengan menggunakan uji chi square dengan menggunakan program SPSS diperoleh PValue yaitu 0.356 dengan tingkat kemaknaan $\alpha=0,05$ maka dapat disimpulkan bahwa, p-Value sebesar 0.356>0,05, sehingga Ha ditolak artinya tidak ada pengaruh antara berat badan lahir dengan kejadian stunting. Perhitungan nilai odds
Ratio (OR) diperoleh nilai yang bukan merupakan risiko untuk terjadinya efek $\mathrm{OR}=1.484$ kali mengalami stunting.

2. Hubungan kejadian stunting berdasarkan status gizi.

Tabel dibawah ini merupakan hasil uji statistik antara status gizi dengan kejadian stunting di Kecamatan Cigandamekar Kabupaten Kuningan.

Tabel 4. Hubungan antara Status Gizi dengan Kejadian Stunting Di Kecamatan Cigandamekar Kabupaten Kuningan

\begin{tabular}{|c|c|c|c|c|c|c|c|c|}
\hline \multirow{3}{*}{ Status Gizi } & \multicolumn{4}{|c|}{ Balita stunting } & \multicolumn{2}{|c|}{ Total } & \multirow{3}{*}{ OR } & \multirow{3}{*}{ P-value } \\
\hline & \multicolumn{3}{|c|}{ Sangat Pendek } & Pendek & \multirow[t]{2}{*}{$\mathbf{F}$} & \multirow[t]{2}{*}{$\%$} & & \\
\hline & $\mathrm{F}$ & $\%$ & 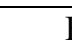 & $\%$ & & & & \\
\hline Kurang gizi & 20 & $51.3 \%$ & 19 & $48.7 \%$ & 39 & 100 & \multirow{2}{*}{3.887} & \multirow{2}{*}{0.002} \\
\hline Baik & 13 & $21.3 \%$ & 48 & $78.7 \%$ & 61 & 100 & & \\
\hline
\end{tabular}

Berdasarkan tabel 4 menunjukan bahwa dari 100 responden, sebagian besar balita stunting sangat pendek dengan status gizi kurang berjumlah 20 orang atau 51.3\%, sedangkan balita stunting secara pendek dengan gizi baik 48 orang atau 78.7\%.Berdasarkan hasil uji statistik dengan menggunakan uji chi square dengan menggunakan program SPSS diperoleh pValue yaitu 0.002 dengan tingkat kemaknaan $\alpha=0,05$ maka dapat disimpulkan bahwa, p-value sebesar $0.002>0,05$, sehingga $\mathrm{Ha}$ diterima adanya pengaruh antara status gizi dengan kejadian stunting. Perhitungan nilai odds Ratio (OR) diperoleh nilai yang menyebabkan efek $\mathrm{OR}=3.887 \mathrm{kali}$ mengalami stunting. diperoleh p-Value yaitu 0.002 dengan tingkat kemaknaan $\alpha=0,05$ maka dapat disimpulkan bahwa, p- Value sebesar $0.002>0,05$, sehingga Ha diterima adanya pengaruh antara status gizi dengan kejadian stunting. Perhitungan nilai odds 
JOURNAL OF MIDWIFERY CARE :

VOL. 01 No. 02, JUNI 2021

DOI: $10.34305 / j m c . v 1 i 02.299$
Ciptaan disebarluaskan di bawah

Lisensi Creative Commons

Atribusi-NonKomersial-

BerbagiSerupa 4.0 Internasional.
Ratio (OR) diperoleh nilai yang menyebabkan efek $\mathrm{OR}=3.887 \quad$ kali mengalami stunting. maka dapat disimpulkan bahwa, p- Value sebesar $0.000<0,05$, sehingga $\mathrm{Ha}$ diterima artinya ada pengaruh antara pemberian ASI dengan kejadian stunting. Setelah dilakukan perhitungan nilai Odds Ratio (OR) diperoleh nilai $\mathrm{OR}=101.667(\mathrm{CI}=23.772-434.800)$ hal ini dapat diinterpretasikan bahwa balita yang ASI menyebabkan efek 101.667 kali mengalami stunting.

\section{Pembahasan}

Pertumbuhan dan perkembangan pada masa bayi memerlukan masukan zatzat gizi yang seimbang dan relatif besar. Namun kemampuan bayi untuk makan dibatasi oleh keadaan saluran pencernaannya yang masih dalam tahap kedewasaan. Satu-satunya makanan yang sesuai dengan keadaan saluran pencernaan bayi dan memenuhi kebutuhan selama berbulan-bulan pertama adalah ASI. Pemberian ASI yang kurang sesuai dapat menyebabkan bayi menderita gizi kurang dan gizi buruk. Padahal kekurangan gizi pada bayi akan berdampak pada gangguan psikomotor, kognitif dan sosial serta secara klinis terjadi gangguan pertumbuhan. Hasil kuesioner kepada ibu balita dan ibu balita terpengaruh oleh adanya susu formula yang mudah dan praktis didapatkan berbagai macam faktor/alasan tidak memberikan ASI Eksklusif kepada anaknya yaitu sebagian ibu balita memiliki kebiasaan memberikan makanan kepada anak sebelum 6 bulan jenis makanan yang diberikan seperti susu formula,bubur SUN, pisang, madu, air putih. Alasan ibu balita memberikan makanan tersebut antara lain ASI tidak keluar, ibu menganggap susu formula lebih praktis Sehingga sebagian besar balita kebutuhan ASI Eksklusif tidak terpenuhi. Kandungan protein dalam ASI cukup tinggi. Salah satu fungsi bagi pertumbuhan dan pemeliharaan jaringan tubuh (Kartasapoetra, 2010).

Protein yang terdapat pada ASI dan susu sapi terdiri dari atas protein whey dan casein. Didalam ASI, lebih banyak terdapat protein whey yang lebih mudah diserap oleh usus bayi. Sedangkan casein cenderung lebih susah dicerna oleh usus bayi, yang banyak terkandung dalam usus (Tejasari, 2010). Berdasarkan uraian tabel 3 dapat disimpulkan bahwa dari 100 responden, berat badan lahir $>2500$ lebih banyak yaitu berjumlah 56 orang atau $56.0 \%$.

E-ISSN $\underline{2774-4167}$ | 145 
JOURNAL OF MIDWIFERY CARE :

VOL. 01 No. 02, JUNI 2021

DOI: $10.34305 / j m c . v 1 i 02.299$
Berdasarkan hasil penelitian, peneliti mengamati bahwa kejadian stunting di Kecamatan Cigandamekar Kabupaten Kuningan riwayat berat badan lahir normal yaitu $>2500$. Hasil uji statistik dengan menggunakan uji chi square dengan menggunakan program komputer diperoleh p-Value yaitu 0.356 dengan tingkat kemaknaan $\alpha=0,05$ maka dapat disimpulkan bahwa, p-Value sebesar $0.356<0,05$, sehingga Ha diterima artinya ada pengaruh antara pemberian ASI dengan kejadian stunting. Setelah dilakukan perhitungan nilai Odds Ratio (OR) diperoleh nilai $\mathrm{OR}=1.484$ $(\mathrm{CI}=0.646-3.442)$ hal ini bukan merupakan risiko untuk terjadinya efek 1.484 kali mengalami stunting.

Penelitian yang dilakukan pada anak balita di wilayah Puskesmas Soromandi NTB yang menyatakan bahwa tidak ada hubungan antara kejadian stunting dengan berat badan lahir merupakan faktor utama dari kejadian stunting utama pada anak umur 12-23 bulan berat badan lahir terhadap kejadian stunting berpengaruh paling tinggi di usia 6 bulan pertama saat lahir kemudian menurun hingga usia 24 bulan. Berat Badan Lahir merupakan salah satu indikator kesehatan pada bayi yang baru lahir. Berat badan lahir merupakan parameter yang sering dipakai untuk menggambarkan pertumbuhan janin pada masa kehamilan. Bayi dengan lahir rendah akan lebih rentan terhadap pengaruh lingkungan yang kurang baik dimasa mendatang (Umboh, 2013). Menurut penelitian Ni Ketut (2017), prediktor terkuat terjadinya stunting pada usia 12 bulan adalah berat badan lahir rendah. Sebagian besar bayi dengan BBLR mengalami gangguan pertumbuhan pada masa kanak-kanak. Berat badan lahir merupakan berat badan bayi yang dicatat pada saat lahir, salah satunya ialah berat badan lahir rendah (BBLR).

Faktor yang mempengaruhi berat badan lahir adalah suatu proses yang berlangsung selama berada dalam kandungan yaitu antara lain sebagai berikut. Faktor internal meliputi: Umur Ibu Kaitannya dengan berat badan lahir kehamilan dibawah 20 tahun merupakan resiko tinggi dibandingkan dengan kehamilan wanita yang cukup umur. Jarak kelahiran Jarak yang dikeluarkan oleh badan koordinasi keluarga berencana (BKKBN) jarak kelahiran adalah 2 tahun atau lebih. Ada berbagai alasan kenapa bayi tersebut memiliki berat badan yang tidak sesuai 
JOURNAL OF MIDWIFERY CARE :

VOL. 01 No. 02, JUNI 2021

DOI: 10.34305/jmc.v1i02.299
Ciptaan disebarluaskan di bawah

Lisensi Creative Commons Atribusi-NonKomersialBerbagiSerupa 4.0 Internasional. standar kelahiran atau yang kita sebut dengan berat badan lahir rendah,salah satu alasan tersebut adalah kurang tepatnya waktu bayi tersebut dilahirkan atau bayi tersebut prematur.

Pada bayi prematur yang disebabkan oleh berbagai faktor. Salah satu faktor tersebut ialah kurang sehatnya kondisi ibu saat kehamilan. Pada masa kehamilan ibu hamil seharusnya lebih banyak memiliki gizi yang cukup sebagai asupan makanan untuk bayi.

Berdasarkan tabel 4 dapat disimpulkan bahwa dari 100 responden, lebih balita berstatus gizi baik yaitu berjumlah 48 orang atau $78.7 \%$. Berdasarkan hasil penelitian, peneliti mengamati bahwa kejadian stunting di Kecamatan Cigandamekar Kabupaten dengan status gizi yang baik, terdapat faktor yang lain seperti cacingan (filariasis) dan faktor genetik. Hasil uji statistik dengan menggunakan uji chi square dengan menggunakan program SPSS diperoleh pValue yaitu 0.002 dengan tingkat kemaknaan $\alpha=0.05$ maka dapat disimpulkan bahwa p- Value sebesar 0.002>0,05, sehingga Ha diterima artinya ada pengaruh antara status gizi dengan kejadian stunting.
Setelah dilakukan perhitungan nilai Odds Ratio (OR) diperoleh nilai $\mathrm{OR}=3.887$ $(\mathrm{CI}=1.616-9.346)$ hal ini bukan terjadinya efek 3.887 kali mengalami stunting.

Stunting pada anak disebabkan kurang nutrisi pada ibu hamil dan asupan yang kurang pada bayi dan anak. Anak stunting merupakan hasil kronis gizi buruk dan kondisi lingkungan yang buruk. Kondisi stunting dapat dicegah dengan cara meningkatkan status gizi ibunya pada masa remaja dan wanita subur, pemberian makanan, akses air yang bersih dan sanitasi lingkungan. Zat pangan senyawa yang terdapat dalam pangan, terdiri dari atas karbohidrat, protein, lemak, vitamin, dan mineral serta bermanfaat pertumbuhan dan kesehatan manusia (Tejasari, 2010). Jadi gizi adalah senyawa- senyawa kimia yang dalam makanan terdiri atas karbohidrat, protein, lemak, vitamin, dan mineral yang mengandung zat tenaga, zat pembangun, zat yang sesuai dengan kebutuhan gizi.

\section{Kesimpulan}

1. Sebagian besar responden (67.0\%) mengalami stunting secara pendek, sebagian besar responden (64.0\%) ASI, 
JOURNAL OF MIDWIFERY CARE :

VOL. 01 No. 02, JUNI 2021

DOI: 10.34305/jmc.v1i02.299
Ciptaan disebarluaskan di bawah

Lisensi Creative Commons

Atribusi-NonKomersial-

BerbagiSerupa 4.0 Internasional. sebagian besar responden $(58.0 \%)$

riwayat berat badan lahir normal $>2500$,

dan sebagian besar responden (61.0\%)

gizi baik.

2. Terdapat hubungan antara pemberian ASI dengan kejadian stunting di Kecamatan Cigandamekar Kabupaten Kuningan $(p=0.000)$

3. Tidak terdapat hubungan antara berat badan lahir dengan kejadian stunting di Kecamatan Cigandamekar Kabupaten Kuningan $(p=0.356)$

4. Terdapat hubungan antara status gizi dengan kejadian stunting di Kecamatan Ciganadamekar Kabupaten Kuningan $(\mathrm{P}=0.002)$.

5. Berdasarkan hasil Penelitian yang dilakukan diharapkan bisa meningkatkan pemberian ASI dan makanan yang bergizi dan ditingkatkan sesuai dengan kebutuhan balita.

\section{Daftar Pustaka}

Dinas Kesehatan Provinsi Jawa Barat. (2016). Profil Kesehatan Provinsi Jawa Barat. Jawa Barat.

Dinkes Kabupaten Kuningan. (2017). Profil Dinas Kesehatan Kabupaten Kuningan. Jawa Barat.

Kartasapoetra, M. (2010). Ilmu gizi. Rineka
Cipta.

Kementerian Kesehatan Republik Indonesia. (2010). Buku Ringkasa Stunting. TNP2K.

Kementerian Kesehatan Republik Indonesia (keputusan menteri kesehatan Nomor: 995/MENKES/SK/XXII/2010 tanggal 30 Desember 2010). (2010). Pedoman gizi seimbang. Direktorat Jenderal Bina Gizi dan Kesehatan Ibu dan Anak.

Laala K.C.G., Punuh M.I., K., \& N.H. (2018). Hubungan antara tinggi badan anak usia 24-59 bulan di Kecamatan Tombatu Utara Kabupaten Minahasa Tenggara. Jurnal KESMAS, 7, 4.

Ni'mah K., N. S. . (2015). Faktor yang berhubungan dengan kejadian stunting pada balita. Journal Media Gizi Indonesia, 10, 13-19.

Ni Ketut. (2017). Riwayat berat badan lahir dengan kejadian stunting pada anak usia bawah dua tahun. Jurnal Kesehatan masyarakat Nasional.

Tejasari. (2010). Nilai-nilai Gizi Pangan. Graha Ilmu.

Umboh, A. (2013). Berat badan lahir rendah dan tekanan darah pada anak. Sagung Seto.

Wiyono, S. (2016). Epidimiologi Gizi. Sagung Seto. 